\title{
Technologies used by nursing managers in Portuguese hospitals
}

\author{
Tecnologias utilizadas por enfermeiros gestores em hospitais portugueses \\ Tecnologías utilizadas por enfermeras gerentes en hospitales portugueses
}

\section{Maria Manuela Ferreira Pereira da Silva Martins ${ }^{a}$ Letícia de Lima Trindade ${ }^{b, c}$ Lara Vandresen $^{\mathrm{d}}$ Maria José Mesquita Gomes Correia Leite Carla Marina Gomes Pereira ${ }^{f}$ Maria José Lumini Landeiro ${ }^{\mathrm{e}}$}

\section{How to cite this article:} Martins MMFPS, Trindade LL, Vandresen L, Leite MJMGC, Pereira CMG. Technologies used by nursing managers in Portuguese hospitals. Rev Gaúcha Enferm. 2020;41:e20190294. doi: https://doi. org/10.1590/1983-1447.2020.20190294
Escola Superior de Enfermagem do Porto (ESEP), Centro de Investigação em Tecnologias e Serviços de Saúde (CINTESIS). Porto, Portugal.

- Universidade do Estado de Santa Catarina (UDESC) Departamento de Enfermagem. Chapecó, Santa Catarina, Brasil.

- Universidade Comunitária da Região de Chapec (UNOCHAPECÓ), Programa de Pós-graduação em Ciências da Saúde. Chapecó, Santa Catarina, Brasil.

${ }^{d}$ Universidade Federal de Santa Catarina (UFSC) Programa de Pós Graduação em Enfermagem. Florianópolis, Santa Catarina, Brasil.

e Escola Superior de Enfermagem do Porto (ESEP). Porto, Portugal.

Escola Superior de Enfermagem do Porto (ESEP), Centro Hospitalar de S. João. Porto, Portugal.

\section{ABSTRACT}

Objective: To analyze the association between the characteristics of nurse managers and the use of information technologies in Portuguese hospitals.

Method: A cross-sectional quantitative study involving 138 nurse managers. The managers answered a questionnaire about the use of key information and communication technologies in management. The findings were submitted to descriptive and analytical statistical analysis.

Results: Women predominated, with more than 25 years in the profession and more than ten in management. It showed that the managers identify the utility and easiness of a singular way for each technology, the use of which is influenced by the nurses' sociooccupational characteristics, their gender, specialization (having it or not), and the time of experience in services and management being significant.

Conclusion: The study contributes to explain and predict the intention to use, as well as the mastery of technologies in hospital management, providing support of choice in the management of services and need for qualification for use.

Keywords: Information technology. Health management. Nursing. Hospital administration. Organization and administration.

\section{RESUMO}

Objetivo: Analisar a associação entre as caraterísticas de enfermeiros gestores e 0 uso de tecnologias de informação e comunicação em hospitais portugueses.

Método: Estudo transversal, quantitativo, envolvendo 138 enfermeiros gestores, que responderam um questionário sobre 0 uso das principais tecnologias de informação e comunicação na gestão. Os achados foram submetidos a análise estatistísca descritiva e analítica.

Resultados: Predominaram as mulheres, com mais de 25 anos na profissão e mais de dez na gestão. Evidenciou que os gestores identificam a utilidade e facilidade de forma singular para cada tecnologia, o uso destas sofre influencia das características sócio laborais dos enfermeiros, sendo significativo o sexo, possuir especialização, o tempo de experiência nos serviços e na gestão.

Conclusão: 0 estudo contribui para explicar e prever a intenção de uso, bem como domínio das tecnologias na gestão hospitalar, fornecendo subsídio de escolha no gerenciamento dos serviços e necessidade de qualificação para utilização.

Palavras-chave: Tecnologia da informação. Gestão em saúde. Enfermagem. Administração hospitalar. Organização e administração.

\section{RESUMEN}

Objetivo: Analizar la asociación entre las características de las enfermeras gestoras y el uso de las tecnologías de la información en los hospitales portugueses.

Método: Estudio cuantitativo y transversal realizado con 138 enfermeras gerentes, quienes respondieron un cuestionario que aborda el uso de tecnologías clave de información y comunicación en la gestión. Los resultados se sometieron a análisis estadísticos descriptivos y analíticos.

Resultados: Predominaron las mujeres, con más de 25 años en la profesión y más de diez en la gestión. Se evidenció que las gerentes identifican de manera única la utilidad y facilidad de cada tecnología, cuyo uso está influenciado por las características socioocupacionales de las enfermeras, y con su género, especialización, y experiencia en servicios y en gestión

Conclusión: el estudio contribuye a explicar y predecir la intención de uso, así como el dominio de las tecnologías en la gestión hospitalaria, proporcionando un respaldo para la elección en la gestión de los servicios y la necesidad de calificación para su uso.

Palabras clave: Tecnología de la información. Gestión en salud. Enfermería. Administración hospitalaria. Organización y administración. 


\section{口INTRODUCTION}

Within the scope of the health services, the hospitals are organizations with a wide range of assistance and that need adequate and consistent management in order to guarantee safe and quality care to their patients. The management of these services involves complex and central actions to advance the tertiary level of care to the population. The act of managing is influenced by different challenges, including people management, risk control and ensuring patient safety, regulation, financing, and available technologies ${ }^{(1-2)}$.

Several studies ${ }^{(3-5)}$ highlight aspects that contribute to the increased complexity in hospital management, to the expansion of the number of patients. This increase/expansion is related not only to the change in the epidemiological profile of the population, but also to the increase in the elderly population and to the complexity of care that individuals and communities require, generating worsening and impacts on the shortage of professionals, as well as expanding the waiting queues for care.

Still, the great diversity of new technologies and the multiple needs of a more demanding population increased health expenditures, making them growing and uncontrollable. This context requires that the role of managers in health organizations acquire a leading and qualified role and that the impact of an intervention or technology provides information for investment decisions( ${ }^{(6)}$.

In the hospital context, the nurse emerges as an important manager, coordinator of people and services indispensable for a better fulfillment of the mission and objectives of these institutions, which provide unique services in the care of patients. In Portugal, the nurse manager is known to have managerial skills that aim to ensure professional and ethical practice in the team he leads ${ }^{(7)}$. This professional acts in the implementation of continuous improvement, in the quality of nursing care, manages the service/unit and the team, thus optimizing responses to the needs of patients, as well as, together with other professionals, stimulating the development of the skills of his subordinates. In addition, nurses must ensure evidence-based care in their professional practice ${ }^{(6)}$.

Technologies are being intensively integrated and considered the basis for the development of organizations. Technologies and technological innovations have impacted the way that the present society is organized and evolves, have undeniable importance in all sectors, potentially in health, proving to be useful, accurate and reliable in the performance of management and care activities ${ }^{(2,4-6)}$. These aspects emerge in the health sector, and it is important to know the needs of health professionals and patients, about the contributions of these technologies, and aspects that can improve their usability ${ }^{(3)}$.

In the context of health management, it is highlighted that the implementation of Information and Communication Technologies (ICT) allows for the operation of processes and for the capture of data from highly varied sources in a more agile and easy way ${ }^{(8)}$.

In this sense, the contribution of technology in management has an influence on the efficiency, effectiveness, and safety of care. Among the technologies, ICTs are considered technical means used to treat information and assist in communication; in other words, ICTs consist of Information Technologies (IT), these include a wide range of products, technologies and services such as mobile and remote health technology, cloud-based services, medical devices, telemonitoring tools, assistant and sensor technologies, electronic health records, among other utilities in health ${ }^{(9)}$.

Different countries ${ }^{(3,10-12)}$ have registered the process of incorporating ICTs, with a constant association between their use and the quality of care provided in the services; however, this is not unanimous in all realities, facing the many challenges of the sector ${ }^{(1)}$. In addition, attitudes towards the use of these work tools are still poorly understood and evaluated ${ }^{(13)}$.

In Portugal, a study on the use of ICTs in the Portuguese health system highlights that, since 2016, the computerization of the National Health System has expanded, with the purpose of expanding the introduction of ICTs in health. This movement aims to ensure services with greater efficiency and quality, and which, at the same time, can indicate interventions for disease prevention in a more responsible and coherent way ${ }^{(7)}$.

Given this context, the question is: What is the association between the characteristics of the profile of nurse managers and the use of information technologies in Portuguese hospitals? Thus, the objective was to analyze the association between the characteristics of nurse managers and the use of information and communication technologies in Portuguese hospitals.

The research is justified by the impact that ICTs have on hospital settings and their repercussion in the work process of nursing managers. Knowing the utility of these devices can assist in determining the most appropriate technologies for use in the work environments of nurses, considering their practicalities and difficulties. Still, the research is relevant because it can better explain, without generalizations, the reasons for choice and resistance in the use and mastery of technologies in management, as well as indicating significant variables in this relation. 


\section{METHOD}

This is a cross-sectional, descriptive and analytical study, guided by the quantitative approach. It was carried out in six Portuguese hospitals. To select these scenarios, it was considered to include hospitals in the Northern region of Portugal, selecting a sample proportional to each stratum, considering the classification (legal nature): university hospital, public hospital, and private hospital.

In Portugal, the latest record made available by the Order of Nurses, indicates the existence of 73,912 nurses, of whom 1,950 are nurse managers, with 24,294 working in the Northern region of the country ${ }^{(14)}$. Thus, a forecast of 643 managers in this Region was obtained, considering a 95\% confidence level and a margin of error of $5 \%$, the sample was 193 nurses. The inclusion criterion used was acting as a nurse manager of a hospital health service in the region of interest for at least three months. Professionals on sick leave for more than three months were excluded. Thus, the final sample of the study was 138 nurse managers, with a margin of error of $7 \%$.

The professionals were requested to reply to a self-completed instrument, questionnaire type, about their socio-employment data (gender, age, academic background, management training, professional practice as a nurse, professional practice in the current service and as a manager); use and knowledge of management technologies (use of technological means, knowledge of management technologies, use of management technologies); and the "use of management technologies" (technological resources that can be used in nursing management, technological resources existing in the institution where they work, for use in nursing management, technological resources that they use in the exercise of nursing management, the utility of each one of these resources, for the exercise of the management functions, the ease of use of each of the technologies, in the exercise of management functions, the utility of each of the technological resources for the exercise of management functions, the ease of use of each of the technological resources for the exercise of management functions). The responses followed Likert scales: does not know/ does not use/ uses a little/ uses/ uses frequently/OR does not know/ useless/not very useful/ useful/very useful, OR does not know/very difficult/ difficult/ easy/ very easy. Data was collected between the months of February 2017 and July 2018 in the workplace by the researchers involved in the research.

Data analysis was performed using the Statistical Package for the Social Sciences (SPSS), version 24.0. p values $\leq 0.05$ were considered statistically significant. The categorical variables were described using relative and absolute frequencies, and the continuous and scalar variables were described using measures of central tendency and dispersion. We used the Chi-square test for association and the Student T Test and the Mann Whitney test to verify differences between medians in the groups, after the Shapiro-Wilk normality test. To correlate years of professional practice in the area of management and other variables, the Pearson's and Spearman's correlation ( $r$ ) tests were used, considering the following: weak correlation between 0 and 0.3 , moderate between 0.3 and 0.6 , strong between 0.6 and 0.9 , and very strong between 0.9 and 1 .

The study was approved by the Ethics and Research Committee of the institutions involved, with the following opinions numbers (No. 166/17/RS, No. 93/CE/JAS and ULS - No. 166/17/RS of CHSJ - No. 4/17). The research was conducted according to the ethical precepts of anonymity, right to information, and participation in the study.

\section{RESULTS}

The study comprised 27 managers from a university hospital (19.6\%), 28 managers from private hospitals (20.3\%) and 83 managers from public hospital centers (60.1\%), all in the North region of Portugal. Among the participants, the majority are female ( $n=78 / 56.5 \%$ ), among the women, $44.9 \%$ are from public hospitals, whereas the distribution of men was similar in all the hospitals. The mean age of the group was 48.8 years old ( \pm 6.6 ), aged between 29 and 60 years old, with a mean of 26.3 years of professional practice $( \pm 6.8$ / minimum of six years to a maximum of 40 years), 11.4 years in management ( $\pm 6.9 /$ minimum of no full year and maximum of 30 years), and eight years in the current service ( \pm 7.8 / minimum of less than a full year and maximum of 35 years).

Among the nurse managers, $2.2 \%(n=3)$ had a doctorate, $19.6 \%(n=27)$ have a master's degree and $90.6 \%(n=125)$ have a specialization, being informed among these seven areas of specialties: nursing surgical physician ( $n=63 / 45.7 \%)$, rehabilitation nursing ( $n=28 / 20.3 \%)$, mental health/ psychiatric nursing $(n=12 / 8.7 \%)$, child/pediatric health nursing ( $n=10 / 7.2 \%)$, obstetric maternal nursing ( $n=6 / 4.3 \%)$, community nursing ( $n=5 / 3.6 \%)$, and geriatric/gerontology nursing ( $n=1 / 0.7 \%)$.

The instrument made it possible to analyze the relation between the socio-labor characteristics of the nurse managers and the use of different ICTs in management, considering the utility and ease of using these work tools, these findings being shown in Table 1. 
Table 1 - Association between the characteristics of the social work profile of the nurse managers and the utility of the management technologies in Portuguese hospitals. Portugal, (PT), North Region, 2019

\begin{tabular}{|c|c|c|}
\hline $\begin{array}{l}\text { Information and } \\
\text { Communication Technology }\end{array}$ & $\begin{array}{l}\text { Considers the technological } \\
\text { resource useful or very useful }\end{array}$ & $\mathbf{p}^{\dagger}$ \\
\hline \multirow{5}{*}{ E-mail } & \multirow{4}{*}{110} & Hospital $=0.000$ \\
\hline & & Type of institution $=0.000$ \\
\hline & & Gender $=0.000$ \\
\hline & & Specialty $=0.000$ \\
\hline & \multirow{3}{*}{72} & Hospital $=0.000$ \\
\hline \multirow[t]{4}{*}{ Chat } & & Type of institution $=0.000$ \\
\hline & & Gender $=0.003$ \\
\hline & \multirow{5}{*}{31} & Years of service $=0.004$ \\
\hline & & Hospital $=0.000$ \\
\hline \multirow[t]{3}{*}{ Discussion group } & & Type of institution $=0.000$ \\
\hline & & Gender $=0.000$ \\
\hline & & Specialty $=0.000$ \\
\hline \multirow{2}{*}{ Videoconference } & \multirow{2}{*}{28} & Hospital $=0.000$ \\
\hline & & Type of institution $=0.000$ \\
\hline \multirow{3}{*}{ Information booklet } & \multirow{2}{*}{95} & Hospital $=0.000$ \\
\hline & & Type of institution $=0.000$ \\
\hline & \multirow{3}{*}{100} & Hospital $=0.000$ \\
\hline \multirow[t]{2}{*}{ Intranet } & & Type of institution $=0.000$ \\
\hline & & Gender $=0.000$ \\
\hline Wiki & 04 & - \\
\hline \multirow{2}{*}{ Forum } & \multirow{2}{*}{13} & Hospital $=0.004$ \\
\hline & & Type of institution $=0.001$ \\
\hline \multirow{4}{*}{ SAPE } & \multirow{4}{*}{99} & Hospital $=0.000$ \\
\hline & & Type of institution $=0.000$ \\
\hline & & Gender $=0.000$ \\
\hline & & Specialty $=0.000$ \\
\hline \multirow{3}{*}{ Sonho } & \multirow{3}{*}{99} & Hospital $=0.000$ \\
\hline & & Type of institution $=0.000$ \\
\hline & & Gender $=0.002$ \\
\hline
\end{tabular}


Table 1 - Cont.

\begin{tabular}{|c|c|c|}
\hline $\begin{array}{l}\text { Information and } \\
\text { Communication Technology }\end{array}$ & $\begin{array}{l}\text { Considers the technological } \\
\text { resource useful or very useful }\end{array}$ & $\mathbf{p}^{+}$ \\
\hline \multirow{3}{*}{ SAM } & \multirow{3}{*}{91} & Hospital $=0.000$ \\
\hline & & Type of institution $=0.000$ \\
\hline & & Gender $=0.000$ \\
\hline \multirow{4}{*}{ Hepic } & \multirow{4}{*}{21} & Hospital $=0.000$ \\
\hline & & Type of institution $=0.000$ \\
\hline & & Gender $=0.000$ \\
\hline & & Specialty $=0.000$ \\
\hline \multirow{3}{*}{ Sinai } & \multirow{3}{*}{115} & Years of management $=0.0002$ \\
\hline & & Hospital $=0.000$ \\
\hline & & Type of institution $=0.002$ \\
\hline \multirow{2}{*}{ Sisqual Ponto } & \multirow{2}{*}{133} & Hospital $=0.000$ \\
\hline & & Type of institution $=0.000$ \\
\hline \multirow{3}{*}{ Aida } & \multirow{3}{*}{119} & Hospital $=0.000$ \\
\hline & & Type of institution $=0.001$ \\
\hline & & Gender $=0.003$ \\
\hline \multirow{3}{*}{ Others } & \multirow{3}{*}{6} & Hospital $=0.000$ \\
\hline & & Type of institution $=0.000$ \\
\hline & & Gender $=0.095$ \\
\hline
\end{tabular}

Source: Research data, 2019

${ }^{\dagger}$ Pearson's Chi-Square - $p \leq 0.05$.

WIKI - Construction of a joint text; / SAPE (Nursing Practice Support System) - a device for recording and planning nursing care activities; / SONHO - support to the administrative service of hospitals, it ensures the control of production and billing, allowing for the export of information for statistical indicators;/ SAM (Physician Support System) - a device for recording medical clinical practices; / Hepic - exchange of measures provided in the European hospital infection control program; / SINAI (Integrated Access System to Information) - a device to access information from other information devices; / Sisqual Ponto - a device used to control attendance of professionals; / Aida - the private registration program of an organization.

WIKI - Construction of a joint text; / SAPE (Nursing Practice Support System) - a device for recording and planning nursing care activities; / SONHO - support to the administrative service of hospitals, it ensures the control of production and billing, allowing for the export of information for statistical indicators; / SAM (Physician Support System) - a device for recording medical clinical practices; / Hepic - exchange of measures provided in the European hospital infection control program; / SINAI (Integrated Access System to Information) - a device to access information from other information devices; / Sisqual Ponto - a device used to control attendance of professionals; / Aida - the private registration program of an organization.

The figures below also illustrate the relation between time in years of service and the perceived utility of the focus groups as technologies for the work of managers and the association identified between years of activity in management and the perceived usefulness of Sinai's resources. 
Table 2 - Association between the characteristics of the socio-labor profile of the nurse managers and the ease of using management technologies in Portuguese hospitals. Portugal, (PT), North Region, 2019

Information and

Communication Technology

E-mail

Chat

Discussion group

Videoconference

Information booklet

Intranet

Wiki

Forum

SAPE

Sonho
106

110

95

106

Considers the technological resource easy or very easy to use

103

99

134

136

71

93

\section{$\mathbf{p}^{\dagger}$}

Hospital $=0.000$

Type of institution $=0.000$

Gender $=0.000$

Specialty $=0.000$

Hospital $=0.000$

Type of institution $=0.000$

Hospital $=0.000$

Type of institution $=0.000$

Hospital $=0.000$

Type of institution $=0.000$

Hospital $=0.000$

Type of institution $=0.000$

Hospital $=0.000$

Type of institution $=0.000$

Gender $=0.000$

Academic degree $=0.000$

Specialty $=0.002$

Hospital $=0.000$

Type of institution $=0.000$

Hospital $=0.000$

Type of institution $=0.000$

$$
\text { Gender }=0.000
$$

Specialty $=0.000$

Hospital $=0.000$

Type of institution $=0.000$

Gender $=0.001$

Specialty $=0.003$

Hospital $=0.000$

Type of institution $=0.000$

Gender $=0.004$

Specialty $=0.000$ 
Table 2 - Cont.

\begin{tabular}{|c|c|c|}
\hline $\begin{array}{c}\text { Information and } \\
\text { Communication Technology }\end{array}$ & $\begin{array}{l}\text { Considers the technological } \\
\text { resource easy or very easy to use }\end{array}$ & $\mathbf{p}^{+}$ \\
\hline SAM & 126 & - \\
\hline \multirow{2}{*}{ Hepic } & \multirow{2}{*}{112} & Hospital $=0.000$ \\
\hline & & Type of institution $=0.000$ \\
\hline \multirow[t]{2}{*}{ Sinai } & \multirow[t]{2}{*}{112} & Hospital $=0.000$ \\
\hline & & Hospital $=0.000$ \\
\hline \multirow[t]{4}{*}{ Sisqual Ponto } & \multirow[t]{4}{*}{112} & Type of institution $=0.000$ \\
\hline & & Gender $=0.001$ \\
\hline & & Hospital $=0.000$ \\
\hline & & Type of institution $=0.000$ \\
\hline \multirow[t]{3}{*}{ Aida } & \multirow[t]{3}{*}{68} & Gender $=0.000$ \\
\hline & & Academic degree $=0.001$ \\
\hline & & Specialty $=0.000$ \\
\hline Others & 128 & Hospital $=0.000$ \\
\hline
\end{tabular}

Source: Research data, 2019

† Pearson's Chi-Square $-p \leq 0.05$.

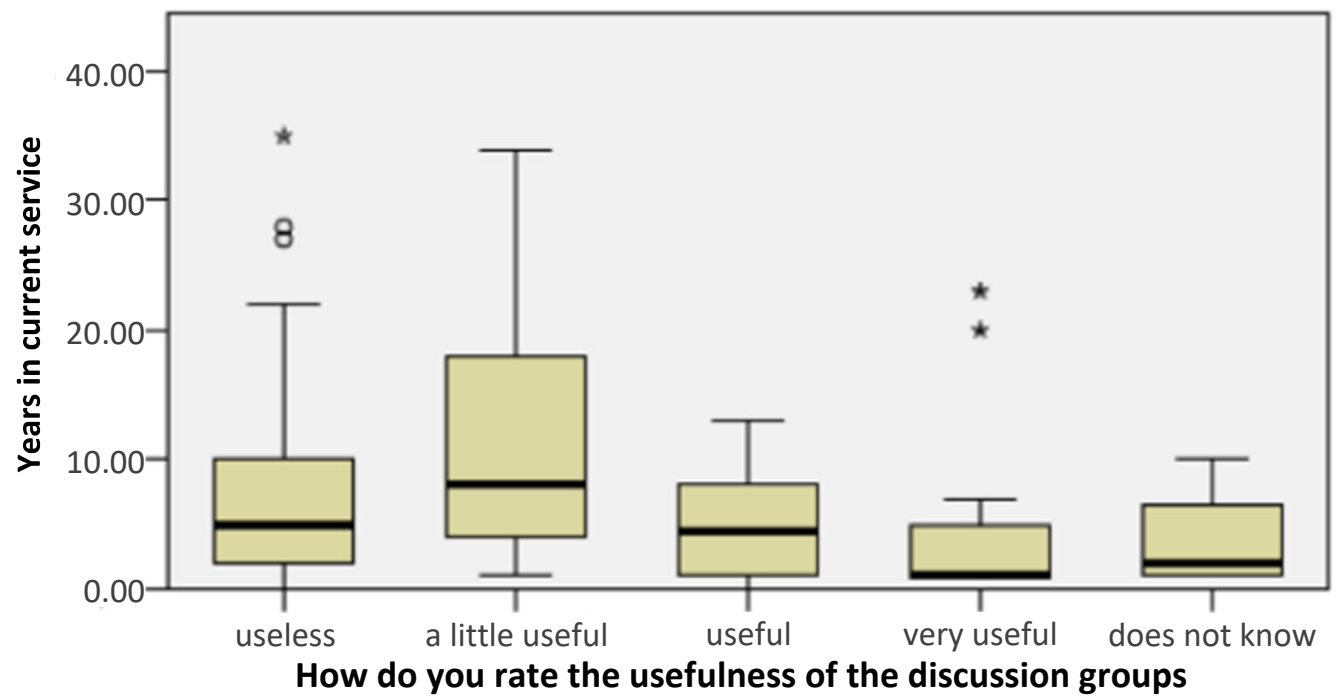

Figure 1 - Relation between length of service and the perception of utility of the discussion groups by the managers, North Region, Portugal, 2019

*Kruskal-Wallis Independent Sample Test

It is worth mentioning that it was also found that, when analyzing each type of hospital and ICT with regard to ease of use, significant differences were found in the use of videoconferences $(p=0.000)$ and the Wiki $(p=0.002)$, being that private hospitals have the best mean values in relation to this domain by the nurse managers. 


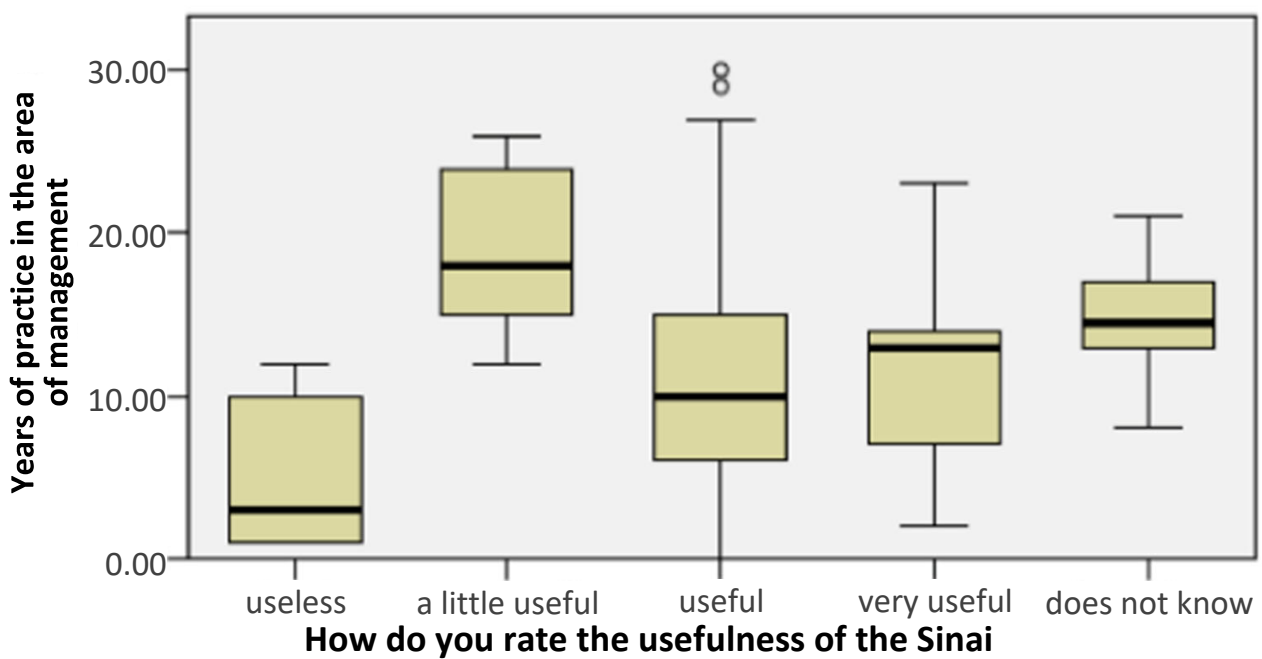

Figure 2 - Relation between the time spent in management and the perception of the utility of the Sinai by the managers, North Region, Portugal, 2019

*Kruskal-Wallis Independent Sample Test

DISCUSSIONS

A predominance of women was identified, with more than 25 years in the nursing profession and more than ten years in management. The hospital setting and the type of hospital (university, public, private) were significant in the perception of practicalities and utilities of the different ICTs surveyed. The managers who work in private hospitals expressed a greater perception of the ease and utility of these work tools, especially E-mail, SINAI and Sisqual, which contribute to the people management process.

The technological resources of the institutions used by the Portuguese nurses are distributed among those of general use, that is, for multiple activities, such as electronic mail, intranet, videoconference, dropbox, Chat, discussion groups, forums, and blogs. Also, those for clinical information record, such as Glint, B-simple, News release, SAPE and SAM clinical support; and those used for management such as Sisqual, Iberia, Conhecer +, RISI, Hepic, and SINAI.

A North American report ${ }^{(12)}$ signals the importance of monitoring the use of technologies in different hospitals in the country, pointing to advances and to the significant increase in technologies in these institutions, as well as differences in the resources available in hospital institutions.

In this sense, studies on the use of ICTs in different care settings contribute to understanding the magnitude of the relation between the use of technologies and the contexts in which they operate, considering specificities such as the material resources available, quantitative and qualitative of workers, as well as their characteristics, as can be evidenced in the findings discussed below.
The gender of the participants was significant for the utility and ease of use of different ICTs, among them.

A study ${ }^{(15)}$ identified that the perceived ease of use and attitude regarding the use of certain technologies significantly influenced the intention to use a particular technology resource for health care. In addition, the results also indicated that women were more strongly influenced by the perceptions of ease of use.

Other researcher ${ }^{(16)}$ stress that, although new generations of women become very early users of technology, even in percentages that exceed men, their presence in the study, design and development of technologies and ICT remains a minority. The authors also resume that innovation and digital knowledge management are mainly male, with the technological education of women being important to reduce the technological gender gap. To improve the participation of women in the production of scientific and technological innovation, they must be inserted early, formally and informally, in the use and development of ICTs in all educational and social systems; paying more attention to the interest expressed by female workers.

Having expertise was statistically important in the perception of utility of electronic mail, discussion group, Sape, Hepic, as well as for ease of use of electronic mail, intranet, forum, Sape, Sonho, and Aida. Other studies ${ }^{(2,17)}$ confirm the relation between the mastery of computer skills and having a specialty among nurses. The academic degree variable was also evidenced in another investigation ${ }^{(18)}$, this being associated with the utility of using the intranet and the ease of use of Aida among the managers of the Portuguese hospitals investigated. 
Training promotes the development of skills which are important for the use of technologies in activities. The ability of each key actor to solve problems (the political or administrative power they have) was identified in another investigation (1) as inversely proportional to their perception of the seriousness of the problems. Training can contribute to the management of the most critical demands that managers face in their daily lives ${ }^{(2,4,10)}$.

The time of experience in the services was significant for the perceived utility of the discussion groups, so as the time of experience in management was for the usefulness of Sinai technology. In Figure I it is possible to analyze that the professionals with less time of service scarcely perceive the utility of the discussion groups as useful and that the majority of the managers do not consider this device useful. This finding may suggest that managers either have little time and space for dialog with the teams, or prefer that it is not mediated by ICTs, and this data instigates other research studies, as well as reflecting on the importance of the transformational leader ${ }^{(17)}$.

In this type of leadership, the leader is able to identify the other's personal and professional needs, developing his own moral characteristics and following professional ethics, as well as a set of skills, including communication ${ }^{(17)}$. However, frequently, when researching the practice of transformational leadership among nurse leaders, difficulties are encountered, which may be related to the lack of recognition of leadership as an attribute, problems in the support of the institution in the formation of leaders, related to vertical management and hierarchical, opposed to the precepts of transformational leadership, which seeks to transform culture and the work environment ${ }^{(19)}$.

Figure II reveals that Sinai was also a technology considered to be of little use by the managers with less experience. It is understood that technologies that are not very useful and difficult to manage have important financial and training costs for institutions and professionals, respectively. On the other hand, when dominated by managers and led teams, ICTs can improve their relationship, as well as promoting

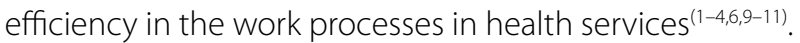

It is observed that the utility and mastery of IT in management is influenced by the profile of the professionals, with the resources being evaluated differently by the professionals. Several researchers ${ }^{(2-3)}$ reinforce that computer skills are essential to the decision-making of nurse managers.

It should also be noted that this is because ICTs can provide potential benefits, but also place additional demands on the professionals, since some devices avail the workers flexible work structures regardless of their location and time. This creates an accessibility pressure, due to an internal obligation of availability, with an effect on the well-being of the professionals who feel they have to be constantly available for work matters. This issue may also intervene in the permanence of nurses in the services.

With the findings it is possible to consider that ICTs should contribute to the qualification of nursing management, with the production of quality indicators that allow for the assessment of the assistance provided by professionals, to promote the safety of the users and the well-being of the worker who handles these work tools; however, they need to master the ICTs. For all these reasons, health institutions need to ask whether the health systems achieve the expected results when they choose to institute a technology $y^{(7)}$, being that professionals can adapt more or less easily and usefully to the use of different ICTs, which enter the context of the health services in an increasing, continuous, and irreversible way.

\section{a CONCLUSION}

The results demonstrated the perception of ease and utility of the ICTs among hospital nurse managers, providing support for the choice of technological devices in management, as well as suitability according to the profile of the nurse manager. As a limitation of this research, it is impossible to deal with all the available technologies, suggesting longitudinal investigations and adaptation to other scenarios, according to the ICTs used in each health care context and health system, as well as in other countries. Among the contributions to teaching, research, and assistance, it is to be highlighted that the ICTs, when employed correctly, can become models for teaching new professionals and qualifying those in the practice, as well as generating a database to serve as a source for the development of investigations. In assistance, the ICTs contribute optimizing the work of nurses and helping to make safe records about the care provided.

It was evidenced that the perception of utility and ease of the nurse managers is unique for each IT, being influenced by the scenario in which they work and their socio-occupational characteristics, especially gender, complementary training, and time of experience in services and management. Thus, it is important to understand which technologies should be inserted in each scenario to enhance their use in management for safe and efficient care.

It is considered that the ITs have great potential to simplify and streamline the management process of nurses in the health services, as well as to improve the coordination of care provision and to lead the teams. For this reason, it is suggested to identify the different organizational challenges to incorporate and standardize the use of these work tools, aligned with the profile of the professionals who use them, 
to invest in the implementation process for their mastery, which requires institutional investments, such as financing for efficiently managing the technologies and incentives in the understanding and follow-up of how they favor efficiency in the care provided, as well as answering to the characteristics and needs of the workers, reducing their work overload.

\section{REFERENCES}

1. Houngbo PT, De Cock Buning T, Bunders J, Coleman HLS, Medenou D, Dakpanon L, et al. Ineffective healthcare technology management in Benin's public health sector: the perceptions of key actors and their ability to address the main problems. Int J Health Policy Manag. 2017;6(10):587-600. doi: https:// doi.org/10.15171/ijhpm.2017.17

2. Jensen R, Guedes ES, Leite MMJ. Informatics competencies essential to decision making in nursing management. Rev Esc Enferm USP 2016;50(1):109-17. doi: https://doi.org/10.1590/50080-623420160000100015

3. Chen PS, Yu CJ, Chen GYH. Applying task-technology fit model to the healthcare sector: a case study of hospitals' computed tomography patientreferral mechanism. J Med Syst 2015;39(8):80. doi: https://doi.org/10.1007/ s10916-015-0264-9

4. Carvalho JV, Wetering ARR, Abreu A. A maturity model for hospital information systems. J Bus Res. 2019;94:388-99. doi: https://doi.org/10.1016/j. jbusres.2017.12.012

5. Miranda GMD, Mendes ACG, Silva ALA. 0 envelhecimento populacional brasileiro: desafios e consequências sociais atuais e futuras. Rev Bras Geriatr Gerontol. 2016;19(3):507-19. doi: https://doi. org/10.1590/1809-98232016019.150140

6. Guerra-Júnior AA, Pires de Lemos LL, Godman B. Health technology performance assessment: real-world evidence for public healthcare sustainability. Int J Technol Assess Health Care. 2017;33(2):279-87. doi: https://doi.org/10.1017/ S0266462317000423

7. Ordem dos Enfermeiros de Portugal. Portugal. Regulamento n.0 101/2015 Regulamentodo PerfildeCompetências do Enfermeiro Gestor.Diárioda República, 2. ${ }^{\text {a série. }} 2015$ mar 10 [cited 2019 Mar 25];(48):5948-52. Available from: https://www.ordemenfermeiros.pt/arquivo/legislacao/Documents/Legislacao OE/Regulamento_101_2015_PerfilCompetenciasEnfermeiroGestor.pdf

8. Aceto $G$, Persico $V$, Pescapé $A$. The role of information and communication technologies in healthcare: Taxonomies perspectives and challenges. 2018. J Netw Comput Appl. 2018;107:125-54. doi: https://doi.org/10.1016/jj.jnca. 2018.02.008

\section{- Corresponding author:}

Maria Manuela Ferreira Pereira da Silva Martins

E-mail:mmartins@esenf.pt
9. Sayles NB. Health information management technology: an applied approach. Chicago, IL: American Health Information Management Association; 2012.

10. Santos AF, Fonseca SD, Araujo LL, Procópio CSD, Lopes EAS, Lima AMLD, et al. Incorporação de tecnologias de informação e comunicação e qualidade na atenção básica em saúde no Brasil. Cad Saúde Pública. 2017;33(5):000172815. doi: https://doi.org/10.1590/0102-311x00172815

11. Donovan JL, Kanaan A0 Gurwitz JH, Tija J, Cutrona SL, Garber L, et al. A pilot health information technology - based effort to increase the quality of transitions from skilled nursing facility to home: compelling evidence of high rate of adverse outcomes. J Am Med Dir Assoc. 2016;17(4):312-7. doi: https:// doi.org/10.1016/j.jamda.2015.11.008

12. Charles D, Gabriel M, Searcy T. Adoption of electronic health record systems among U.S. Non-Federal Acute Care Hospitals: 2008-2014. ONC Data Brief. 2015 [cited 2019 Jul 20];(23):1-10. Available from: https://www.healthit.gov/sites/ default/files/data-brief/2014HospitalAdoptionDataBrief.pdf

13. Oliveira MR, Correia VGA, Dantas EOM, Moreira TMM, Torres RAM. Validation of the attitude scale for information and communications technologies. Acta Paul Enferm. 2019;32(1):79-86. doi: https://doi.org/10.1590/19820194201900011

14. Ordem dos Enfermeiros (PT) [Internet]. Lisboa: Ordem dos Enfermeiros; 2019 [cited 2019 Jun 06]. Estatisticas de enfermeiros; [aprox. 1 screen]. Available from: https:// www.ordemenfermeiros.pt/sala-de-imprensa/estatística-de-enfermeiros

15. Dutta B, Peng M, Sun SL. Modeling the adoption of personal health record (PHR) among individual: the effect of health-care technology self-efficacy and gender concern. Libyan J Med. 2018;13(1):1500349. doi: https://doi.org/10.1080/199 32820.2018.1500349

16. Jiménez RGP, Fernández (J. La brecha de género en la educación tecnológica. Ensaio: Aval Pol Públ Educ. 2016;24(92):743-71. doi: https://doi. org/10.1590/S0104-403620160003000010

17. Ferreira VB, Amestoy SC, Silva GTR, Felzemburgh RDM, Santana N, Trindade $\mathrm{LL}$, et al. Liderança transformacional na prática dos enfermeiros em um hospital universitário. Acta Paul Enferm. 2018;31(6):644-50. doi: https://doi. org/10.1590/1982-0194201800088

18. Collins SA, Alexander D, Moss J. Nursing domain of Cl governance: recommendations for health IT adoption and optimization. J Am Med Inform Assoc. 2015;22(3):697-706. doi: https://doi.org/10.1093/jamia/ocu001

19. Fischer SA. Transformational leadership in nursing: a concept analysis. J Adv Nurs. 2016;72(11):2644-53. doi: https://doi.org/10.1111/jan.13049

\section{Funding:}

Higher School of Nursing of the University of Porto.

\section{Associate editor:}

Dagmar Elaine Kaiser

Received: 08.03.2019

Approved: 03.06.2020

\section{Editor-in-chief:}

Maria da Graça Oliveira Crossetti 